\title{
Pedunculate oak stands in the catchments of the river Vorskla's tributaries
}

\author{
Viktor Tkach, Oleksandr Bondar, Maksym Rumiantsev*
}

\begin{abstract}
Ukrainian Research Institute of Forestry and Forest Melioration named after G. M. Vysotsky, Pushkinska Str. 86,
\end{abstract} 61024, Kharkiv, Ukraine

\begin{abstract}
Tkach, V., Bondar, O., Rumiantsev, M., 2020. Pedunculate oak stands in the catchments of the river Vorskla's tributaries. Folia Oecologica, 47 (1): 70-80.

The aim of the study was to analyze the origin of oak stands within the catchments of the Vorskla's tributaries and to describe their state. Covering 60,900 ha, pedunculate oak (Quercus robur L.) stands prevail and cover $51.1 \%$ of the total forest area of 119,200 ha in the catchment areas of the River Vorskla's tributaries. The way oak stands are distributed in regards to trophotopes points at favourable conditions for their growth, as $81.7 \%$ of the area is a fresh fertile oak forest site type. Forest stands aged $41-80$ years (39.8\% of the total area) and $81-120$ years $(50.4 \%)$ are prevailing. Natural oak stands cover almost $66.5 \%$ and planted ones grow at $33.5 \%$. Distribution of oak stands in regards to the functional categories of forests shows a significant predominance of the protective forests. They cover $46.6 \%$ of the total area. The commercial forests cover $23.0 \%$, the recreational ones make $18.8 \%$ and the forests with conservational, academic, historical and cultural purpose cover $11.6 \%$. Distribution patterns of oak forests in the catchments of the River Vorskla's tributaries should be considered in the forest management in order to conserve their biodiversity and enhancing the performance of important environmental, protective, recreational and other functions. The article contains results of the study on the natural regeneration of Quercus robur and other wood species under the canopy of oak stands and on felling sites. The further research perspectives are a thorough study of the stand characteristics and the typological structure of forests in terms of certain wood species in the catchments of rivers all over Ukraine. It will help developing principles for the catchment and landscape zonation.
\end{abstract}

\section{Keywords}

forest category, natural regeneration, Quercus robur L., River Vorskla, tributary's

\section{Introduction}

Forests in the catchment areas (floodplain forests) is a unique natural grouping as they grow under the conditions of annual periodical flooding with different duration as part of spring floods (FIQUEPRON et al., 2013). They are also affected by continuous stream (LANGAT et al., 2019; SANTOS et al., 2019) and alluvial processes (Guillon et al., 2019; LANZONI et al., 2019). These specific aspects cause a considerable typological diversity of the forest biocoenoses (Polyakov and TeETER, 2005; Lelli et al., 2019).
Floodplain forests perform various important functions, such as water conservation (DEL CAMPO et al., 2019a, 2019b), soil protection (WIŚNIEWSKI and MÄRKER, 2019; ZHAO et al., 2019), recreational functions (UPTON et al., 2015; CARvalho Ribeiro et al., 2018) and others. River pollution and shallowing are to a great extent caused by the decreasein forested areas and deterioration of floodplain forests in general.

The urgent topic for the region of the study is a fieldprotective forestation. Being located in catchments, protective forest shelterbelts significantly influence the efficiency of agrocoenosis and ensure a stable ecological 
environment. Final felling in oak stands is allowed to carry out in the exploitable forests only. They are forbidden in other categories, and only forming and sanitation felling is carried out being aimed at planting economically valuable oak stands.

The analysis of the distribution of oak stands according to the categories of forests points at the fact that it greatly differs within the catchments of certain tributaries. For that reason, defining the categories of forests in the catchments of the tributaries of large rivers has to be corrected during the next basic forestry surveying.

Pedunculate oak (Quercus robur L.) is one of the main forest forming species in the Central European forests (STEPHAn et al., 2018; MöLDER et al., 2019). In Ukraine, the area covered with oaks is more than 1.7 million ha (RumiAnTSEv et al., 2018). Forest stands with oak prevailing is a primary forest type within a fresh fertile maplelime forest site type which is a zonal forest type within the Forest-Steppe zone in Left-Bank Ukraine (OsTAPENKo and TKACH, 2002).

Absence of necessary forestry measures taken in time in oak forests may lead to the change of the main forest type to other ones - less valuable secondary forests with Acer platanoides L., Acer campestre L., Fraxinus excelsior L., Tilia cordata Mill., Ulmus glabraHuds., Populus tremula $\mathrm{L}$. and others.

Generally, the oak forests in Left-Bank Forest-Steppe are rather broadly characterized according to the forestry aspect. Their modern state and productivity were studied by Holovach et. al. (2013); the health condition was analyzed by Meshrova (2011) and Holovach (2010); the specific aspects of planting highly-productive oak stands taking into account the typological structure of the forests were studied by MARCHUK et al. (2000); LUNACHEVSKYI et al. (2015) studied the changes in forest mensuration characteristics after the improvement felling; specificities in forming natural regeneration under the canopy of oak stands and in the felling areas were analyzed in several studies (Sklyar and Dehtyaryov, 2013; Chigrinets and IGNATENKO, 2015; RUMIANTSEV et al., 2018).

The study of the typological and age structure of oak forests, as well as their distribution according to the forest categories is a relevant topic. Such research within the catchments of the tributaries of the River Vorskla has not been done. However, there are studies restricted to the description of forest stands according to the forest mensuration variables, or defining their productivity.

The aim of the study was to analyze the origin of oak stands within the catchments of the Vorskla's tributaries and to describe their state.

\section{Materials and methods}

To define the boundaries of the Vorskla's tributaries, we used MapInfo Professional 12.5 and the vector map of Ukraine. The boundaries of the catchment areas were determined by the watershed lines passing the points from which the slope profiles spread to opposite directions. Such points are located at the spots with the maximum bend of horizontals. Watershed divides passed along the ridges through the peaks and saddles.

To analyze the forest area in the forestry enterprises within the catchments of the Vorskla's tributary's, we developed an electronic subcompartment database using the forest inventory data of the Ukrderzhlisproekt Production Association as on 2016, and converted it from the .vff into .mdb format of MS Access by means of the NewUnPackOHOTA programme developed in the Laboratory of New Information Technologies of the Ukrainian Research Institute of Forestry and Forest Melioration (URIFFM). Data selection necessary for the further calculations was exported into the .xls format in Microsoft Excel 2016 in compliance with the developed algorithm (VEDMID et al., 2006).

The study covers forests (an area over 119,200 ha) within 24 catchments of the Vorskla's tributaries (four catchments were forestless) in the forestry enterprises in Poltava, Kharkiv and Sumy Regions in Ukraine.

Geographical coordinates of the limiting points of the study region were as follows: north $35^{\circ} 07^{\prime} 48^{\prime \prime}, 50^{\circ} 44^{\prime} 34^{\prime \prime}$, south $34^{\circ} 09^{\prime} 37^{\prime \prime}, 48^{\circ} 58^{\prime} 11^{\prime \prime}$, west $33^{\circ} 52^{\prime} 15^{\prime}$ ', $49^{\circ} 09^{\prime} 25^{\prime \prime}$, and east $36^{\circ} 03^{\prime} 37^{\prime}, 50^{\circ} 27^{\prime} 1^{\prime \prime}$ ' (Fig. 1).

The typological analysis of forests was done in compliance with the main methodical statements of the forestecological (Ukrainian) school of the forest typology. Thus, P. Pogrebnyak and D. Vorobyov have identified the forest site type, the forest type and the type of forest stand as the main taxonomic units in the Ukrainian typology (OsTAPENKO and TKACH, 2002).

The forest site type (other similar names are the edatope, type of habitat conditions, type of forest area, the edaphic conditions type) is a combination of forested non-forested lands with similar soil and hydrological conditions, which have similar forest site capacity effect. Climatic parameters can be different. The leading signs of establishment of the forest site type - species composition of plants and its productivity. Live soil cover: The auxiliary - features of relief, soil types, groundwater level.

Each forest site simultaneously belongs to a certain level of soil fertility and soil moisture, and is trophotope and hygrotope simultaneously. A combination of fertility with soil moisture makes a forest site type. Therefore, a cell in the edaphic grid (PogrebNyAK, 1955) represents the first and the largest unit in the forest and ecological aspect in the forest typology, namely the forest site type.

According to its location in the edaphic grid, a forest site type gets a binary (double) name which consists of the words defining the fertility group (trophotope) and moisture group (hygrotope). So, a forest site type has its own identification. When indexing the forest site types, the following letters of the Latin alphabet are used to define trophotopes: A (infertile site), B (fairly infertile site), C (fairly fertile site), and D (fertile site), and the Arabic numerals are used for hygrotopes, namely 0 (very dry), 1 (dry), 2 (fresh), 3 (moist), 4 (damp), and 5 (wet). For instance, dry infertile site type is referred to as $A_{1}$, fresh fairly infertile site type is $B_{2}$, moist fairly fertile site type is $\mathrm{C}_{3}$, damp fertile site type is $\mathrm{D}_{4}$, etc. (Table 1 ). 

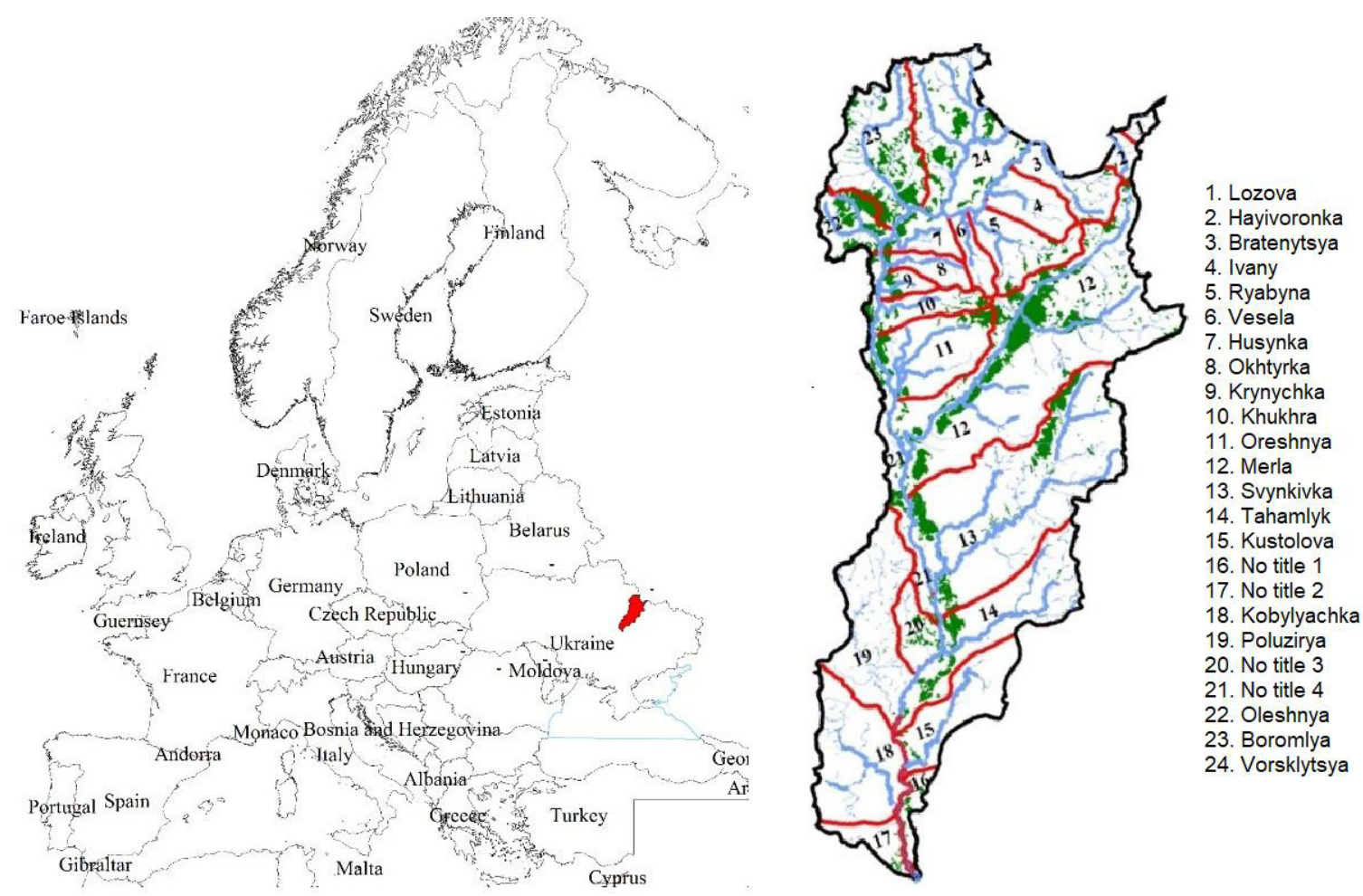

Fig. 1. Sketch map of the research object (catchment area of the Vorskla's tributaries).

Table 1. The classification a forest site type according to its location in the edaphic grid (PogreBNYAK, 1955)

\begin{tabular}{|c|c|c|c|c|}
\hline \multirow[b]{2}{*}{ Hygrotopes } & \multicolumn{4}{|c|}{ Trophotopes } \\
\hline & $\begin{array}{c}\mathrm{A} \\
\text { Infertile pine site } \\
\text { type }\end{array}$ & $\begin{array}{c}\text { B } \\
\text { Fairly infertile pine site } \\
\text { type }\end{array}$ & $\begin{array}{c}\text { C } \\
\text { Fairly fertile (usually } \\
\text { hardwood) site type }\end{array}$ & $\begin{array}{c}\text { D } \\
\text { Fertile (usually } \\
\text { hardwood) site type }\end{array}$ \\
\hline $\begin{array}{c}0 \\
\text { Very dry }\end{array}$ & $\begin{array}{c}\mathrm{A}_{0} \\
\text { Very dry infertile } \\
\text { pine site type }\end{array}$ & $\begin{array}{c}\mathrm{B}_{0} \\
\text { Very dry fairly infertile } \\
\text { pine site type }\end{array}$ & $\begin{array}{c}\mathrm{C}_{0} \\
\text { Very dry fairly fertile } \\
\text { site type }\end{array}$ & $\begin{array}{c}\mathrm{D}_{0} \\
\text { Very dry fertile site } \\
\text { type }\end{array}$ \\
\hline $\begin{array}{c}1 \\
\text { Dry }\end{array}$ & $\begin{array}{l}\quad \mathrm{A}_{1} \\
\text { Dry infertile pine } \\
\text { site type }\end{array}$ & $\begin{array}{c}\mathrm{B}_{1} \\
\text { Dry fairly infertile pine } \\
\text { site type }\end{array}$ & $\begin{array}{c}\mathrm{C}_{1} \\
\text { Dry fairly fertile site } \\
\text { type }\end{array}$ & $\begin{array}{c}\mathrm{D}_{1} \\
\text { Dry fertile site type }\end{array}$ \\
\hline $\begin{array}{c}2 \\
\text { Fresh }\end{array}$ & $\begin{array}{c}\mathrm{A}_{2} \\
\text { Fresh infertile pine } \\
\text { site type }\end{array}$ & $\begin{array}{l}\mathrm{B}_{2} \\
\text { Fresh fairly infertile pine } \\
\text { site type }\end{array}$ & $\begin{array}{c}\mathrm{C}_{2} \\
\text { Fresh fairly fertile site } \\
\text { type }\end{array}$ & $\begin{array}{c}\mathrm{D}_{2} \\
\text { Fresh fertile site type }\end{array}$ \\
\hline $\begin{array}{c}3 \\
\text { Moist }\end{array}$ & $\begin{array}{c}\mathrm{A}_{3} \\
\text { Moist infertile pine } \\
\text { site type }\end{array}$ & $\begin{array}{c}\mathrm{B}_{3} \\
\text { Moist fairly infertile pine } \\
\text { site type }\end{array}$ & $\begin{array}{c}\mathrm{C}_{3} \\
\text { Moist fairly fertile site } \\
\text { type }\end{array}$ & $\begin{array}{c}\mathrm{D}_{3} \\
\text { Moist fertile site type }\end{array}$ \\
\hline $\begin{array}{c}4 \\
\text { Damp }\end{array}$ & $\begin{array}{c}\mathrm{A}_{4} \\
\text { Damp infertile pine } \\
\text { site type }\end{array}$ & $\begin{array}{c}\mathrm{B}_{4} \\
\text { Damp fairly infertile } \\
\text { pine site type }\end{array}$ & $\begin{array}{c}\mathrm{C}_{4} \\
\text { Damp fairly fertile site } \\
\text { type }\end{array}$ & $\begin{array}{c}\mathrm{D}_{4} \\
\text { Damp fertile site type }\end{array}$ \\
\hline $\begin{array}{c}5 \\
\text { Wet, or swamp }\end{array}$ & $\begin{array}{l}\mathrm{A}_{5} \\
\text { Wet infertile pine } \\
\text { site type }\end{array}$ & $\begin{array}{l}\mathrm{B}_{5} \\
\text { Wet fairly infertile pine } \\
\text { site type }\end{array}$ & $\begin{array}{c}\mathrm{C}_{5} \\
\text { Wet fairly fertile site } \\
\text { type }\end{array}$ & $\begin{array}{c}\mathrm{D}_{5} \\
\text { Wet fertile site type }\end{array}$ \\
\hline
\end{tabular}


The researchers defined the categories of the forests in accordance with "The order of division of forests into the categories and defining particularly protective forest sites" which was approved by the Act of the Cabinet of Ministers of Ukraine No 733 dated May 16, 2007 (Poryadok podilu lisiv na katehoriyi ta vydilennya osoblyvo zakhysnykh lisovykh dilyanok, 2007). According to the criteria given in this document, forests fall into the following categories:

- Forests with conservational, academic, historical and cultural purposes (wildlife sanctuaries, nature significant sites, wildlife reserves, regional landscape parks, etc.);

- Recreational forests (within human settlements): They perform several functions, namely a recreational, a sanitary and a health improving ones. People spend their free time there, do sports, go hiking or get their health-resort treatment;

- Protective forests (mainly these are anti-erosion forests which prevent soil erosion);

- Exploitable forests (mentioned to meet the national economy's needs in fine wood on account of final felling operations).

Developmental characteristics of the young growth of economically valuable species were studied within the Vorskla River catchment. Eight sample plots were established under the canopy of mixed oak stands of a natural origin aged over 100 years and with a relative density of stocking from 0.6 to 0.8 and two sample plots on the clear felling sites (aged 2-3 years). The sample plots were established in state-owned enterprises Trostyanets Forestry and Okhtyrka Forestry in Sumy Region in 2018. The forest site types were fresh $\left(D_{2}\right)$ and moist $\left(D_{3}\right)$ fertile sites. The natural regeneration was accounted and assessed on the circular plots. Each plot was of $10 \mathrm{~m}^{2}(R=178 \mathrm{~cm})$ and covered at least $5 \%$ of the forest area on a sample plot. There were at least 100 circular plots for recording natural regeneration.

Registered healthy, with no visible signs of damage, natural forest regeneration was divided into groups according to wood species, age and height. The natural forest regeneration success was assessed by means of the URIFFM scale (PASTERNAK, 1990). When assessing, we took into account both a quality and quantity of the natural regeneration in terms of wood species.

The study results were analyzed by means of applied computer programmes and GIS-technologies.

\section{Results}

The analysis of the forest surveying materials within the study region's forest resources (as on 2016) shows that the total area of forests in the Vorskla's catchment is 119,200 ha. In that, oak stands are prevailing. They make 60,900 ha which is $51.1 \%$ of the total area. Overall, oak stands were found in 20 catchments of the Vorskla's tributary's. The area they covered varied from 12 ha (Okhtyrka tributary catchment) to over 13,000 ha (Merla tributary catchment)

The way oak stands in the catchment of the River Vorskla are distributed in regards to trophotopes, has its pecu- liarities. Thus, a vast part of oak stands which is $88.3 \%$ of the total area of oak forests is concentrated in fertile sites, while they make $10.6 \%$ in fairly fertile sites and $1.0 \%$ and $0.1 \%$ in fairly infertile pine sites and in infertile pine sites respectively (Table 2 ).

On studying the distribution of oak stand area in the catchments of the Vorskla's tributary's according to trophotopes (Table 2), we found out that their proportion was the largest - almost in all the catchments of the tributary's - in fertile sites, and it varied from $24.4 \%$ (Krynychka tributary catchment) to $100 \%$ (Bratenytsya, Ryabyna, and Kustolova tributary's catchments) of the total area. Furthermore, there are no oak stands at all in the catchments of two tributary's (Husynka and Okhtyrka tributary's catchments).

As for fairly fertile sites, oak stands grow within 16 catchments of the Vorskla's tributary's, and their proportion varies from $1.3 \%$ (Vorsklytsya tributary catchment) to $82.9 \%$ (Okhtyrka tributary catchment) of the total area of oak forests. There are no oak stands at all in four catchments of the tributary's.

Oak stands within fairly infertile pine sites grow in nine catchments of the Vorskla's tributary's and their proportion varies from $0.4 \%$ (Khukhra tributary catchment) to $100 \%$ (Husynka tributary catchment) of the total area of oak forests. There are no oak stands at all in 11 catchments of the tributary's.

In poor conditions (infertile pine sites) oak stands cover a small area within one catchment only. It is the catchment area of the Tahamlyk tributary. And there are no oak stands at all within 19 catchments of the tributary's.

In the catchments of the Vorskla's tributary's the majority of oak stands are characterized by natural origin (coppice, seeds or coppice and seeds). Their part covers $66.5 \%$ of the total area of oak forests. The rest $(33.5 \%)$ of the oak forests are planted (Fig. 2).

Distribution of the area of oak stands in the tributaries' catchments in terms of their origin has some specific aspects. Thus, the part of oak forests of natural origin varied from $42.8 \%$ (No title 2 tributary catchment) to $92.2 \%$ (Tahamlyk tributary catchment) of the total area of oak forests.

In the whole, natural oak forests grow within 19 catchments of the Vorskla's tributary's, while planted oak stands grow entirely in Okhtyrka tributary catchment only.

Planted oak stands grow within 20 catchments of the Vorskla's tributary's, and their proportion within these tributary's varies from 7.8\% (Tahamlyk tributary catchment) to $100 \%$ (Okhtyrka tributary catchment).

The study in the sample plots within the Boromlya, Vorsklytsya, and Khukhra tributary's catchments detects that in the floodplain of the River Vorskla, mixed stands are formed with pedunculate oak prevailing, both of a vegetative (coppice) origin of the second or third generation (clear-cutting was repeatedly done and the stands were renewed in a natural vegetative way - by coppice shoots produced by stools) and of a natural origin by seeds. A natural regeneration of the main species both under the forest canopy (regeneration established before cutting of the main crop) and on felling sites (the one established 
Table 2. Distribution of oak stands in the catchments of the Vorskla's tributary's in terms of prevailing trophotopes (\%)

\begin{tabular}{|c|c|c|c|c|c|c|c|c|c|c|}
\hline \multirow{3}{*}{$\begin{array}{l}\text { Vorskla's } \\
\text { tributaries }\end{array}$} & \multirow{3}{*}{$\begin{array}{c}\text { A } \\
\text { Infertile pine } \\
\text { site type } \\
\text { Total }\end{array}$} & \multicolumn{2}{|c|}{$\begin{array}{c}\text { B } \\
\text { Fairly infertile } \\
\text { pine site type } \\
\end{array}$} & \multicolumn{3}{|c|}{$\begin{array}{l}\text { C } \\
\text { Fairly fertile (usually } \\
\text { hardwood) site type }\end{array}$} & \multicolumn{4}{|c|}{$\begin{array}{c}\text { D } \\
\text { Fertile (usually } \\
\text { hardwood) site type } \\
\end{array}$} \\
\hline & & \multirow{2}{*}{ Total } & \multirow{2}{*}{$\frac{\text { including* }}{\mathrm{B}_{2}}$} & \multirow{2}{*}{ Total } & \multicolumn{2}{|c|}{ including* } & \multirow{2}{*}{ Total } & \multicolumn{3}{|c|}{ including* } \\
\hline & & & & & $\mathrm{C}_{2}$ & $\mathrm{C}_{3}$ & & $\mathrm{D}_{1}$ & $\mathrm{D}_{2}$ & $\mathrm{D}_{3}$ \\
\hline Hayivoronka & - & - & - & 1.5 & - & - & 98.5 & 24.4 & 71.1 & 3.0 \\
\hline Bratenytsya & - & - & - & - & - & - & 100 & 6.1 & 88.2 & 5.7 \\
\hline Ryabyna & - & - & - & - & - & - & 100 & 2.3 & 97.5 & 0.1 \\
\hline Husynka & - & 100 & 91.2 & - & - & - & - & - & - & - \\
\hline Okhtyrka & - & 17.1 & 17.1 & 82.9 & - & 82.9 & - & - & - & - \\
\hline Krynychka & - & 18.8 & 16.2 & 56.9 & 56.9 & - & 24.4 & 16.8 & 7.6 & - \\
\hline Khukhra & - & 0.4 & 0.2 & 5.4 & 2.7 & 2.6 & 94.2 & 6.4 & 85.0 & 2.8 \\
\hline Oreshnya & - & 0.6 & 0.6 & 23.3 & 22.0 & 1.1 & 76.2 & 1.4 & 74.7 & 0.1 \\
\hline Merla & - & 1.8 & 1.7 & 14.4 & 12.5 & 1.4 & 83.8 & 9.5 & 73.2 & 1.1 \\
\hline Svynkivka & - & 0.7 & 0.6 & 11.4 & 8.4 & 2.0 & 87.9 & 1.3 & 83.4 & 3.2 \\
\hline Tahamlyk & 0.3 & 22.2 & 17.0 & 53.1 & 25.4 & 27.7 & 24.4 & 0.1 & 13.9 & 10.4 \\
\hline Kustolova & - & - & - & - & - & - & 100 & - & 43.9 & 56.1 \\
\hline No title 1 & - & 5.1 & 2.8 & 9.6 & 5.0 & 4.2 & 85.4 & 3.3 & 76.6 & 5.5 \\
\hline No title 2 & - & - & - & 4.1 & 1.4 & 1.9 & 95.9 & 0.4 & 93.1 & 2.4 \\
\hline Kobylyachka & - & - & - & 13.0 & 13.0 & - & 87.0 & 3.7 & 83.2 & - \\
\hline Poluzirya & - & - & - & 1.6 & 1.6 & - & 98.4 & 1.2 & 96.2 & 1.0 \\
\hline No title 4 & - & - & - & 14.7 & 11.3 & 0.1 & 85.2 & 9.3 & 72.5 & 3.4 \\
\hline Oleshnya & - & - & - & 5.5 & 5.4 & 0.1 & 94.5 & 0.5 & 93.8 & 0.2 \\
\hline Boromlya & - & - & - & 10.5 & 10.2 & 0.2 & 89.5 & 0.5 & 88.8 & 0.2 \\
\hline Vorsklytsya & - & - & - & 1.3 & 1.3 & - & 98.2 & 6.5 & 90.8 & 0.9 \\
\hline Vorskla & 0.1 & 1.0 & 0.8 & 10.6 & 8.9 & 1.1 & 88.3 & 4.8 & 81.7 & 1.7 \\
\hline
\end{tabular}

*prevailing forest site type in corresponding trophotopes; $\mathrm{B}_{2}$, fresh fairly infertile pine site type; $\mathrm{C}_{2}$, fresh fairly fertile site type; $C_{3}$, moist fairly fertile site type; $D_{1}$, dry fertile site type; $D_{2}$, fresh fertile site type; $D_{3}$, moist fertile site type.

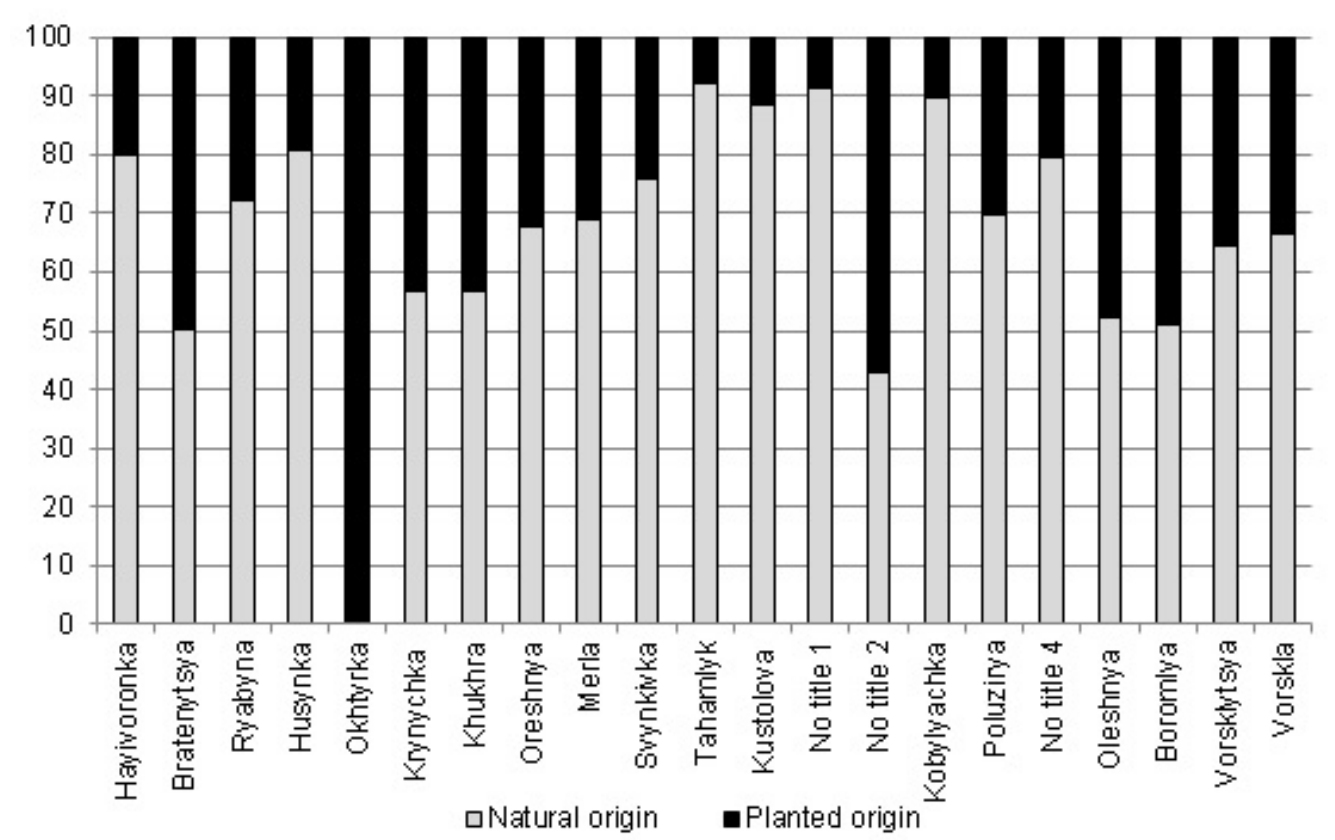

Fig. 2. Distribution of oak stands in the catchments of the Vorskla's tributary's according to their origin (\%). 
after cutting of the main crop) is poor (Table 3). In general, seven wood species were registered in the composition of the natural regeneration, with a low proportion of oak. Thus, no more than 7001 -3-year-old oak trees of seed origin grow within 1 ha under the canopy of mature and overmature oak stands, and almost all of them are damaged by powdery mildew (Erysiphe alphitoides Griffon \& Maublanc). Over time, they will turn into stumps.

Oak can also be seen in a small number (200-400 trees per ha) within the cutting areas after clear-cutting (the width of the cutting strip varied from $51 \mathrm{~m}$ to $100 \mathrm{~m}$ ) as part of the final cutting of parent stands.

Distribution of oak forests in the catchments of the Vorskla's tributary's shows that the stands aged of 81-120 years prevail in the stand area here. They make $50.4 \%$ of the total area. The stands aged of 41-80 years have a slightly less proportion (39.8\%). And the stands aged $1-40$ years and 121 and older years make $6.2 \%$ and $3.6 \%$ respectively (Fig. 3). The average age of oak stands depending on their origin is 87 years for the stands of a vegetative (coppice) origin, 93 years for those of a natural seed origin and 58 years for the oak stands planted by seeds.

The oak stands aged $41-80$ years, which is middleaged, grow within all the 20 catchments of Vorskla's tributary's. They make from $31.4 \%$ (No title 4 tributary catchment) to $82.9 \%$ (Okhtyrka tributary catchment) of the total area of oak forests in these catchments.

The oak stands aged 1-40 and 81-120 years grow within 19 catchments of the Vorskla's tributary's. Their propor- tion varies from $0.5 \%$ (Kobylyachka tributary catchment) to $17.1 \%$ (Okhtyrka tributary catchment) and from $28.2 \%$ (Husynka tributary catchment) to $63.6 \%$ (Kustolova tributary catchment) of the total area of oak forests in these catchments respectively.

The oak stands aged 121 years and older grow within 11 catchments of the Vorskla's tributary's. They make from $0.5 \%$ (Vorsklytsya tributary catchment) to $12.7 \%$ (Khukhra tributary catchment) of the total area of oak forests in these catchments.

On analyzing the age structure of the oak forests in the catchments of the Vorskla's tributary's, we came to the conclusion that it is unbalanced, and middle-aged stands (aged 41-80 years) significantly prevail in the area. It happened due to the fact that after the World War II great efforts were done in forest renewal and reforestation. In this way, vast areas with young forests were established, mostly a man-made origin. Therefore, one of the main tasks for the modern forest management concerning the oak forests in Ukraine, and, in particular, in the catchments of large rivers, is to take necessary forestry measures to optimize age structures of the stands.

According to "The order of division of forests into the categories and defining particularly protective forest sites" (Poryadok podilu lisiv na katehoriyi ta vydilennya osoblyvo zakhysnykh lisovykh dilyanok, 2007) oak forests within the catchments of the Vorskla's tributary's belong to all categories, namely the forests of recreational, academic, historical and cultural purposes; the recreational forests; the protective

Table 3. Forest mensuration characteristics of natural oak stands in the catchments of the Boromlya, Vorsklytsya, and Khukhra tributary's and the quantity of their natural regeneration

\begin{tabular}{|c|c|c|c|c|c|c|c|c|}
\hline \multirow{2}{*}{$\begin{array}{l}\text { Sample } \\
\text { plot } \\
\text { number }\end{array}$} & \multirow{2}{*}{$\begin{array}{l}\text { Vorskla's } \\
\text { tributaries }\end{array}$} & \multirow{2}{*}{$\begin{array}{c}\text { Forest site } \\
\text { type }\end{array}$} & \multicolumn{3}{|c|}{ Characteristic of oak stands } & \multicolumn{3}{|c|}{$\begin{array}{c}\begin{array}{c}\text { The number of natural } \\
\text { regeneration }\end{array} \\
\text { including } \\
\text { pedunculate oak }\end{array}$} \\
\hline & & & Stand composition & $\begin{array}{l}\text { Age* } \\
\text { (years) }\end{array}$ & $\begin{array}{l}\text { Relative } \\
\text { density of } \\
\text { stocking }\end{array}$ & Total & $\begin{array}{l}\text { Thousand } \\
\text { stems ha }^{-1}\end{array}$ & $\%$ \\
\hline 1 & Boromlya & $\mathrm{D}_{2}$ & Oak $100 \%$ & 105 & 0.8 & 4.6 & 0.3 & 7 \\
\hline 2 & Boromlya & $\mathrm{D}_{3}$ & Oak $70 \%-\mathrm{N}-$ Maple $20 \%$ & 111 & 0.8 & 8.8 & 0.5 & 6 \\
\hline 3 & Boromlya & $\mathrm{D}_{2}$ & $\begin{array}{c}\text { Oak } 60 \% \text {-Lime } 20 \%- \\
\text { Ash } 20 \%\end{array}$ & 113 & 0.7 & 6.3 & 0.2 & 3 \\
\hline 4 & Vorsklytsya & $\mathrm{D}_{2}$ & Oak $90 \%-$ Ash $10 \%$ & 151 & 0.6 & 9.0 & 0.7 & 8 \\
\hline 5 & Vorsklytsya & $\mathrm{D}_{2}$ & Oak $80 \%-$ Ash $20 \%$ & 160 & 0.7 & 9.7 & 0.6 & 6 \\
\hline 6 & Vorsklytsya & $\mathrm{D}_{3}$ & Oak $80 \%$-Alder $10 \%$ & $3 *$ & - & 7.5 & 0.4 & 5 \\
\hline 7 & Khukhra & $\mathrm{D}_{2}$ & Oak $100 \%$ & 108 & 0.7 & 5.5 & 0.3 & 5 \\
\hline 8 & Khukhra & $\mathrm{D}_{2}$ & $\begin{array}{c}\text { Oak } 80 \%-\text { Lime } 10 \%- \\
\text { N-Maple } 10 \%\end{array}$ & 128 & 0.8 & 5.8 & 0.1 & 2 \\
\hline 9 & Khukhra & $\mathrm{D}_{3}$ & Oak 90\%-Lime 10\% & 130 & 0.7 & 6.2 & 0.3 & 5 \\
\hline 10 & Khukhra & $\mathrm{D}_{3}$ & Oak $80 \%-$ Ash $20 \%$ & $2 *$ & - & 3.1 & 0.2 & 7 \\
\hline
\end{tabular}

*age of felling; Oak, pedunculate oak (Quercus robur L.); Ash, common ash (Fraxinus excelsior L.); N-Maple, Norway maple (Acer platanoides L.); Lime, small-leafed lime (Tilia cordata Mill.); Alder, common alder (Alnus glutinosa (L.)

Gaerth.). 


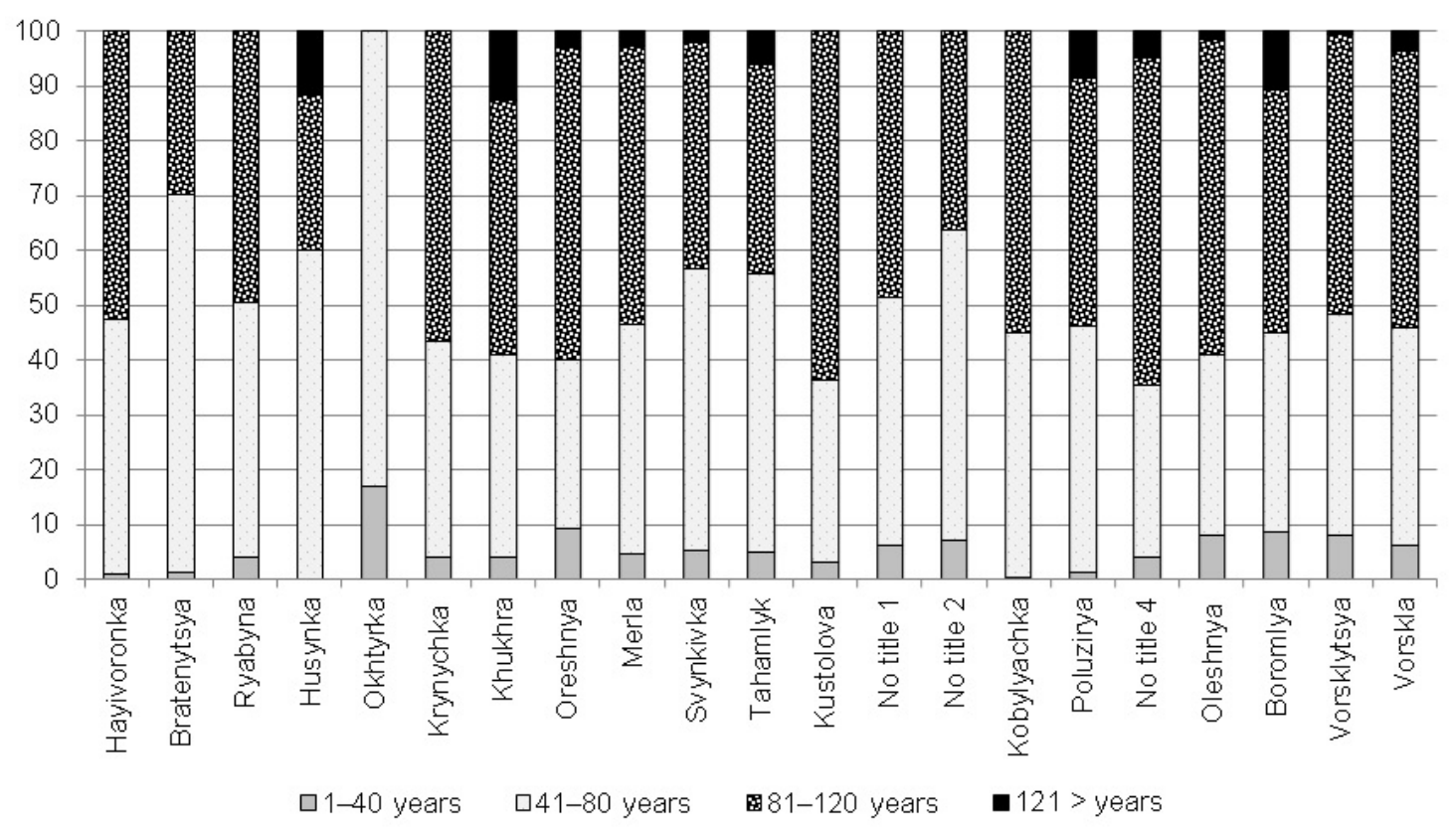

Fig. 3. Distribution of oak stands in the catchments of the Vorskla's tributaries according to age groups (\%).

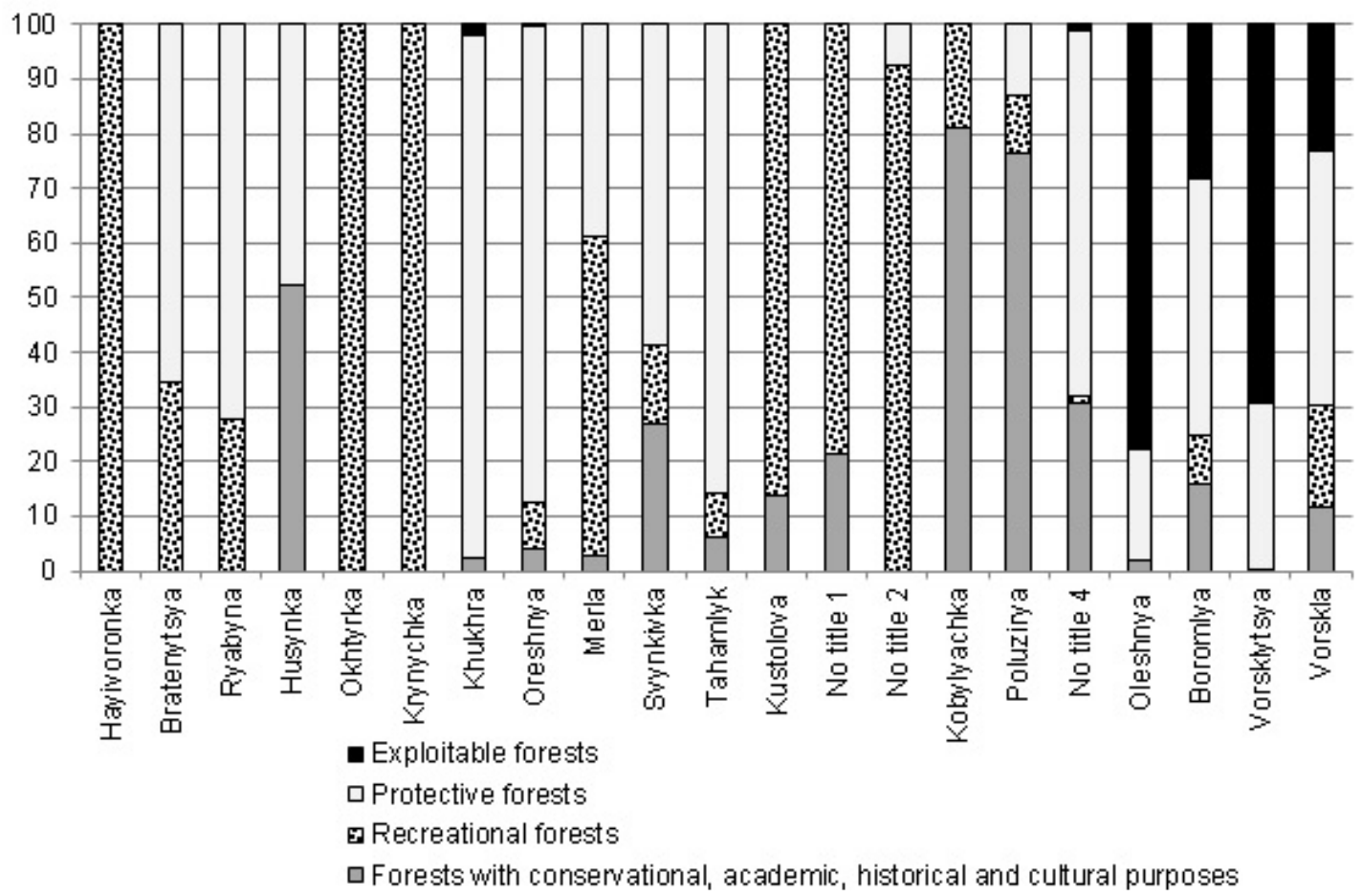

Fig. 4. Distribution of the oak stands area in the catchments of the Vorskla's tributary's according to the categories of forests (\%).

forests and the exploitable ones (Fig. 4).

The smallest area, which is 7,000 ha or $11.6 \%$ of the total area of oak forests, is covered with the forests with recreational, academic, historical and cultural purposes. The oak stands which belong to the recreational forests category cover 11,500 ha or $18.8 \%$. The exploitable forests, which are the forests where final felling operations are allowed, make nearly a quarter $(23.0 \%)$ of the total area of oak forests. The protective forests cover the largest area of the total area of oak stands. Mostly they represent erosion-preventing forests which prevent soil erosion (wind and water ones).

\section{Discussion}

On the catchments of the Vorskla's tributaries the typological structure of the forests was studied by TKACH et al. 
(2016) and the forest inventory structure of oak stands by SolodovnYK et al. (2009).

When analyzing oak forests within the middle reaches of the River Vorskla (Sumy Region, Ukraine), SoLODOvNYK et al. (2009) revealed that the stands of a natural origin made $55 \%$ and planted ones $-45 \%$ of the total area. They emphasized on the fact that the age structure of oak forests, both natural and planted, was unbalanced. Thus, the middle-aged stands (41-80 years) were significantly prevailing; their proportion was $88 \%$ for natural stands and $72 \%$ for planted ones. Our results for all catchments of the Vorskla's tributary's within the upper, the middle, and the lower reaches (Sumy Region, Poltava Region, and Kharkiv Region) confirmed the conclusions (SolodovnYK et al., 2009) that the middle-aged oak stands of a natural origin prevail in the region.

Based on the analysis of the typological structure and biological diversity in the forests within small catchments of the River Vorskla, TKACH et al. (2016) have found that the highest typological diversity is typical for the forests in the catchment of the Merla tributary (34 forest types) and the lowest one is in the forests in the catchment of the Hayvoronka tributary ( 5 forest types). It is connected by the diversity of geomorphological, landscape, edaphic and climatic conditions for forming of the forests. Growing number of the forest types complicates the forest management in that area.

After the analysis of the area of oak stands in the catchments of the Vorskla's tributary's according to trophotopes, we have concluded that even within one river basin (the river Vorskla's basin) but on its different tributaries, the distribution of oak stands in terms of the forest site types is quite different. They can be found in nearly all types of the forest sites. This fact underlines the necessity to implement differentiation systems into the management, considering a location of tributaries' catchments. As forestry in Ukraine is based on the forest typology principles, when taking forestry measures in the catchments of the Vorskla's tributary's, it is absolutely necessary to take into account the typological diversity of oak forests.

The average age of oak stands we considered is almost identical to those defined by HoLOvach et. al. (2013) when they analyzed the forest inventory materials for oak forests in Left-Bank Forest-Steppe. A slight difference in age was detected for planted oak stands. For example, within the catchments of the Vorskla's tributary's the average age is 58 years old, while in all Left-Bank Forest Steppe is 53 years old.

In their research Meshrova and Didenko (2017) have confirmed that the average age of natural oak stands of a seed origin in the oak forests within Left-Bank ForestSteppe tends to grow with an increase of geographical latitude, and planted oak stands of a seed origin have a decreased vitality in comparison to natural oak stands.

Oak stands of a seed origin, comparing to those of a coppice origin, turned to be more resilient to negative environmental factors, as well as more long-lived among the oak stands of a natural origin. We have found that in the catchments of the Vorskla's tributary's, the same as within Left-Bank Forest-Steppe in general, according to the data
(HolovaCH et. al., 2013), the oak stands of a coppice origin prevail. Biological characteristics of the coppice oak stands result in the decline of their resilience after they turn 60-70 years old. Enormous and uncontrolled accumulation of old stands causes their weakness. It brings about not only decline of the species and assortment structure of the stands, but also weakness of their ecological and protective functions (TKACH and HolOVACH, 2009). Taking into account this fact, forestry actions in oak forests have to be addressed to regeneration of the oak stands of a natural seed origin.

Furthermore, natural oak stands are more resilient to diseases and pests than planted ones (DíAZ-MAROTO and Vila-LAMEIRo, 2008; Granger et al., 2018), which is particularly important for the areas with the climate change (HärKöNEN et al., 2019; SHANNON et al., 2019). It is important to take into account this specific aspect when managing floodplain forests.

One of the core aspects in forestry, during renewal of oak forests, is to use a natural regeneration of pedunculate oak and other economically valuable species. The quantity a natural regeneration of pedunculate oak and other economically valuable species is an important reserve that will help on the seed renewal of highly productive, biologically stable natural oak stands. It will also to forecast their further development and preserve their genetic potential. In the era of a gradual warming and the climate aridity increase, this topic becomes particularly relevant (LUCE et al., 2016; De Groote et al., 2018; Vanhellemont et al., 2019).

The success of oak natural regeneration depends on many factors, namely on a quantity of oak in the stand and its age, relative density of stocking, seed yield of acorns, a sufficient warmth, moisture, and finally light and development of the shrub and grass layers (IKAUNIECE et al., 2012; Vizoso-Arribe et al., 2014; MuHAMED et al., 2015; WoziwodA et al., 2019).

It can be explained, first of all, by the periodicity of the pedunculate oak's fruiting, namely cycling of seed and non-seed years. In the current climate conditions, this biological peculiarity of an oak is characterized by the increase of a time period between its seed years. Thus, within latest 10 years (2009-2018) an oak had only three seed years $(2010,2013$ and 2018). It is caused by the increase of the anthropogenic effect onto all the components of the environment.

The results of our preliminary study (RUMIANTSEV et al., 2018) defined the optimal conditions for emergence, preservation and further successful growth of the oak reproduction and its valuable accompanying species (light which should be at least $20 \%$ of that on an open space; an oak's fruit bearing; moisture of the litter and soil; live groundcover of Aegopodium podagraria L.; relative density of stocking within $0.6-0.7$; absence of a thick shrub layer).

Meshrova and Didenko (2017) found out that oak stands of a natural seed origin are poorly represented in young forests (up to 40 years old). The fact that young oak forests of a natural origin are nearly absent shows the decline of an oak's potential capacity for regeneration. That 
is why it is necessary to urgently work out a set of forestry activities aimed at growing natural oak stands. It can be obtained by means of simultaneous selection or successive regeneration cuttings as principal cuttings in the exploitable forests and regeneration ones in non-exploitable forests. Moreover, actions to undertake activities to promote natural regeneration of oak should be adopted. In terms of that, periodicity of oak fruiting must be considered as well.

\section{Conclusions}

The total area of oak forests in the Vorskla's catchment is 60,900 ha where stands of a natural origin prevail. The largest area of oak stands is the area with the most favourable for growth conditions, namely fertile forest sites.

Age structure of oak forests is unbalanced. The stands aged 41-80 and 81-120 years significantly prevail in terms of area; young stands make a small share. The forest management strategy in river catchments must be aimed at the optimization of the age structure of the forests and at natural forest regeneration. Nearly a half of the area with oak stands is ascribed to the category of the protective forests and nearly a quarter to the category of the exploitable forests. The oak forests within the catchments of the Vorskla's tributary's both have important ecological protective functions and meet the population's needs in valuable oak wood.

Our investigations cover the whole area of the catchments of the tributaries (within Ukraine) and, therefore, our results have scientific and practical value. Moreover, could promote the development of appropriate management activities in oak stands throughout the whole catchment area as part of the landscape.

The further research perspectives are a thorough study of the stand characteristics and the typological structure of forests in terms of certain wood species in the catchments of rivers all over Ukraine. It will help developing principles for the catchment and landscape zonation.

\section{Acknowledgements}

This work contains results from the scientific project „To improve the methods and technologies of fellings in the flatland forests of Ukraine" (grant 0115U001196), which was supported by the State Forest Resources Agency of Ukraine. The authors are grateful to the staff of the Laboratory of Forestry of the Ukrainian Research Institute of Forestry and Forest Melioration named after G. M. Vysotsky for their support and assistance with this research. The authors wish to thank the Executive Editor, the Editor of the manuscript and the anonymous reviewers for helping to improve the earlier versions of this paper.

\section{References}

Carvalho Ribeiro, S.M., Soares Filho, B., Leles Costa, W., Bachi, L., Ribeiro de Oliveira, A., Bilotta, P.,
SaAdi, A., Lopes, E., O’Riordan, T., Lôbo Pennacchio, H., Queiroz, L., Hecht, S., Rajão, R., Oliveira, U., CIoCe SAmpaio, C., 2018. Can multifunctional livelihoods including recreational ecosystem services (RES) and non timber forest products (NTFP) maintain biodiverse forests in the Brazilian Amazon? Ecosystem Services, 31: 517-526. https://doi.org/10.1016/j.ecoser.2018.03.016

Chigrinets, V.P., IgnatenKo, V.A., 2015. Osoblyvosti nasinnoho vidnovlennya duba zvychayinoho $\mathrm{v}$ zalezhnosti vid stupenya zridzhenosti derevostanu $\mathrm{v}$ umovakh svizhoyi klenovo-lypovoyi dibrovy Livoberezhnoho Lisostepu Ukrayiny [Features of pedunculate oak regeneration depending on forest stands thinning degree in the fresh maple-linden oak forests of the Left-bank Forest-Steppe of Ukraine]. Bulletin of Sumy NAU. Series: Agronomy and Biology, 9: 224-227.

De Groote, S.R.E., Vanhellemont, M., Baeten, L., Van den Bulcke, J., Martel, A., Bonte, D., Lens, L., VerHEYEN, K., 2018. Competition, tree age and size drive the productivity of mixed forests of pedunculate oak, beech and red oak. Forest Ecology and Management, 430: 609617. https://doi.org/10.1016/j.foreco.2018.08.050

Del Campo, A.D., González-Sanchis, M., García-Prats, A., Ceacero, C.J., Lull, C., 2019a. The impact of adaptive forest management on water fluxes and growth dynamics in a water-limited low-biomass oak coppice. $A g$ ricultural and Forest Meteorology, 264: 266-282. https:// doi.org/10.1016/j.agrformet.2018.10.016

Del Campo, A.D., González-Sanchis, M., Molina, A.J., García-Prats, A., Ceacero, C.J., Bautista, I., 2019 b. Effectiveness of water-oriented thinning in two semiarid forests: the redistribution of increased net rainfall into soil water, drainage and runoff. Forest Ecology and Management, 438: 163-175. https://doi.org/10.1016/j. foreco.2019.02.020

Díaz-Maroto, I.J., Vila-Lameiro, P., 2008. Pedunculate oak (Quercus robur L.) silviculture in natural stands of NW Spain: environmental conditioners. Forest Ecology and Management, 256 (4): 702-711. https://doi. org/10.1016/j.foreco.2008.05.023

Fiquepron, J., Garcia, S., Stenger, A., 2013. Land use impact on water quality: valuing forest services in terms of the water supply sector. Journal of Environmental Management, 126: 113-121. https://doi.org/10.1016/j.jenvman.2013.04.002

Granger, J.J., Buckley, D.S., Sharik, T.L., Zobel, J.M., DeBord, W.W., Hartman, J.P., Henning, J.G., KeySER, T.L., Marshall, J.M., 2018. Northern red oak regeneration: 25-year results of cutting and prescribed fire in Michigan oak and pine stands. Forest Ecology and Management, 429: 467-479. https://doi.org/10.1016/j. foreco.2018.06.003

Guillon, S., Thorel, M., Flipo, N., Oursel, B., Claret, C., Fayolle, S., Bertrand, C., Rapple, B., Piegay, H., Olivier, J.-M., Vienney, A., Marmonier, P., Franquet, E., 2019. Functional classification of artificial alluvial ponds driven by connectivity with the river: consequences for restoration. Ecological Engineering, 127: 394-403. https://doi.org/10.1016/j.ecoleng.2018.12.018

Härkönen, S., Neumann, M., Mues, V., Berninger, F., Bronisz, K., Cardellini, G., Chirici, G., Hasenauer, H., Koehl, M., Lang, M., Merganicova, K., Mohren, 
F., Moiseyev, A., Moreno, A., Mura, M., Muys, B., Olschofsky, K., Del Perugia, B., Rørstad, P.K., SolBerg, B., Thivolle-Cazat, A., Trotsiuk, V., MäKelä, A., 2019. A climate-sensitive forest model for assessing impacts of forest management in Europe. Environmental Modelling \& Software, 115: 128-143. https://doi. org/10.1016/j.envsoft.2019.02.009

HolOvach, R.V., 2010. Sanitarnyi stan pryrodnykh dubovykh derevostaniv Livoberezhnoho Lisostepu [Sanitary condition of natural oak forest stands in the Left-bank ForestSteppe]. Forestry and Forest Melioration, 117: 183-186.

Holovach, R.V., Lunachevskyy, L.S., Kobets, O.V., 2013. Suchasnyyi stan derevostaniv duba zvychayinoho Livoberezhnoho Lisostepu Ukrayiny [Present state of pedunculated oak stands in Ukrainian Left-Bank ForestSteppe]. In Proceedings of International scientific and practical Internet conference Nauka na sluzhbi silskoho hospodarstva. Ukraine, Mykolayiv, March 5, $2013 .$. Mykilayiv: Mykolayivska DSDS IZZ, p. 55-56.

IKaunieCE, S., Brūmelis, G., Kondratovičs, T., 2012. Naturalness of Quercus robur stands in Latvia, estimated by structure, species, and processes. Estonian Journal of Ecology, 61 (1): 64-81. https://doi.org/10.3176/ eco.2012.1.07

Langat, P.K., Kumar, L., Koech, R., 2019. Monitoring river channel dynamics using remote sensing and GIS techniques. Geomorphology, 325: 92-102. https://doi. org/10.1016/j.geomorph.2018.10.007

Lanzoni, S., Ferdousi, A., Tambroni, N., 2019. River banks and channel axis curvature: Effects on the longitudinal dispersion in alluvial rivers. Advances in Water Resources, 113: 55-72. https://doi.org/10.1016/j.advwatres.2017.10.033

Lelli, C., Bruun, H.H., Chiarucci, A., Donati, D., Frascaroli, F., Fritz, Ö., Goldberg, I., Nascimbene, J., TøTtrup, A.P., Rahbek, C., Heilmann-Clausen, J., 2019. Biodiversity response to forest structure and management: comparing species richness, conservation relevant species and functional diversity as metrics in forest conservation. Forest Ecology and Management, 432: 707717. https://doi.org/10.1016/j.foreco.2018.09.057

Luce, C.H., Vose, J.M., Pederson, N., Campbell, J., MilLar, C., Kormos, P., Woods, R., 2016. Contributing factors for drought in United States forest ecosystems under projected future climates and their uncertainty. Forest Ecology and Management, 380: 299-308. https://doi. org/10.1016/j.foreco.2016.05.020

LunaCheVSKYi, L.S., LuK'Yanets, V.A., MusiIEnKo, S.I., 2015. Vplyv rubok dohlyadu riznoyi intensyvnosti na taksatsiyini pokaznyky dubovykh derevostaniv $\mathrm{v}$ umovakh svizhoho hrudu [Effect of thinning of different intensity on the taxation parameters of oak stands in fresh fertile conditions]. Forestry and Forest Melioration, 126: 66-73.

MarchuK, YU.M., Mykhalkiv, V.M., Kuprina, N.P., IhNATENKO, V.A., 2000. Produktyvnist, struktura ta stan dubovykh tsenoziv v bahatykh umovakh Livoberezhnoho Lisostepu [Productivity, structure and condition of oak coenoses in the best quantities of the Left-bank Forest Steppe]. Scientific Herald of NULES of Ukraine. Series: Forestry, 25: 143-152.

Meshkova, V.L., 2011. Dynamika sanitarnoho stanu dubovykh derevostaniv u Livoberezhnomu Lisostepu
Ukrainy pislya provedennya lisohospodarskykh zakhodiv [Dynamics of sanitary condition of oak stands in the Leftbank Forest Steppe of Ukraine after forest management operations]. Forest Journal, 1: 28-32.

Meshrova, V.L., Didenko, M.M., 2017. Vikova struktura ta zberezhenist pryrodnykh dubovykh derevostaniv Livoberezhnoho Lisostepu [Age structure and survival of natural oak stands in the Left-bank Forest-Steppe]. The Bulletin of Kharkiv National Agrarian University. Series: Soil Science, Agricultural Chemistry, Agriculture, Forestry, and Soil Ecology, 1: 155-164.

Mölder, A., Meyer, P., Nagel, R.-V., 2019. Integrative management to sustain biodiversity and ecological continuity in Central European temperate oak (Quercus robur, Quercus petraea) forests. Forest Ecology and Management, 437: 324-339. https://doi.org/10.1016/j. foreco.2019.01.006

Muhamed, H., Lingua, E., Maalouf, J.-P., Michalet, R., 2015. Shrub-oak seedling spatial associations change in response to the functional composition of neighbouring shrubs in coastal dune forest communities. Annals of Forest Science, 72 (2): 231-241. https://doi.org/10.1007/ s13595-014-0419-8

OstaPENKo, B.F., TKACH, V.P., 2002. Lisova typolohiya [Forest typology]. Kharkiv: Pleyada. 204 p.

PASTERnAK, P.S. (ed.), 1990. Spravochnik lesovoda [Forester's reference]. Kyiv: Urozhay. 295 p.

Pogrebnyak, P.S., 1955. Osnovy lesnoy tipologii. Izdanie 2-e [Basics of forest typology. Second edition]. Kyiv: Akademiya Nauk USSR. 456 p.

Polyakov, M., Teeter, L., 2005. The influence of regulatory forest policy tools on biodiversity measures for forests in Ukraine. Forest Policy and Economics, 7 (6): 848-856. https://doi.org/10.1016/j.forpol.2004.04.002

Poryadok podilu lisiv na katehoriyi ta vydilennya osoblyvo zakhysnykh lisovykh dilyanok [The order of division of forests into the categories and defining particularly protective forest sites]. Cabinet of Ministers of Ukraine from 27.07.2007. No 733. [cit. 2020-01-13]. https://zakon. rada.gov.ua/laws/show/733-2007-\%D0\%BF

Rumiantsev, M., LuK'yanets, V., Musienko, S., MostepaNYUK, A., OBolonyK, I., 2018. Main problems in natural seed regeneration of pedunculate oak (Quercus robur L.) stands in Ukraine. Forestry Studies, 69: 7-23. https:// doi:10.2478/fsmu-2018-0008

Santos, M.G.M., Hartley, A.J., Mountney, N.P., Peakall, J., Owen, A., Merino, E.R., Assine, M.L., 2019. Meandering rivers in modern desert basins: implications for channel planform controls and prevegetation rivers. Sedimentary Geology, 385: 1-14. https://doi.org/10.1016/j. sedgeo.2019.03.011

Shannon, P.D., Swanston, C.W., Janowiak, M.K., HanDler, S.D., Schmitt, K.M., Brandt, L.A., ButlerLEOPOLD, P.R., ONTL, T., 2019. Adaptation strategies and approaches for forested watersheds. Climate Services, 13: 51-64. https://doi.org/10.1016/j.cliser.2019.01.005

Sklyar, V.G., Dehtyaryov, V.M., 2013. Osoblyvosti pryrodnoho ponovlennya providnykh tsenozoutvoryuyuchykh vydiv v urochyshchi "Retytska dacha" [Features of natural regrowth of dominate forest tree species in the "Retitska Dacha" array]. Bulletin of Sumy NAU, 3 (25): 11-13. Solodovnyk, V.A., HoroshKo, V.V., ShVachKa, O.S., 2009. 
Analiz taksatsiinoyi budovy derevostaniv v mezhakh serednoyi techiyi richky Vorskla Sumskoyi oblasti [An analysis of the taxonomic structure of forest stands within the middle reaches of the Vorskla River in the Sumy region]. The Bulletin of Kharkiv National Agrarian University. Series: Soil Science, Agricultural Chemistry, Agriculture, Forestry and Soil Ecology, 2: 175-178.

Stephan, J.M., Teeny, P.W., Vessella, F., Schirone, B., 2018. Oak morphological traits: between taxa and environmental variability. Flora, 243: 32-44. https://doi. org/10.1016/j.flora.2018.04.001

TKaCh, L.I., Bondar, O.B., SOlODOVNYK, V.A., 2016. Typolohichna struktura i bioriznomanittya lisiv malykh vodozboriv richky Vorskla [Typological structure and biodiversity of forests in small water catchment areas of the Vorskla river]. Scientific Herald of National University of Life and Environmental Sciences of Ukraine. Series: Forestry and Decorative Gardening, 238: 56-65.

Tkach, V.P., Golovach, R.V., 2009. Suchasnyy stan pryrodnykh dubovykh derevostaniv $\mathrm{v}$ Livoberezhnomu Lisostepu Ukrayiny [Current condition of natural oak stands in the Left-bank Forest-Steppe of Ukraine]. Forestry and Forest Melioration, 116: 79-84.

Upton, V., Ryan, M., O’Donoghue, C., Ni Dhubhain, A., 2015. Combining conventional and volunteered geographic information to identify and model forest recreational resources. Applied Geography, 60: 69-76. https:// doi.org/10.1016/j.apgeog.2015.03.007

Vanhellemont, M., Sousa-Silva, R., Maes, S.L., Van den Bulcke, J., Hertzog, L., De Groote, S.R.E., Van Acker, J., Bonte, D., Martel, A., Lens, L., VerheyEN, K., 2019. Distinct growth responses to drought for oak and beech in temperate mixed forests. Science of The Total Environment, 650 (2): 3017-3026. https://doi. org/10.1016/j.scitotenv.2018.10.054

Vedmid, M.M., Meshkova, V.L., ZhezhKun, A.M., 2006. Alhorytm dlya vyyavlennya dilyanok malotsinnykh molodnyakiv u dibrovakh za materialamy lisovporyadkuvannya [Algorithm for reveal of low valuable young stands in the oakeries by forest inventory data]. Forestry and Forest Melioration, 110: 54-58.

Vizoso-Arribe, O., Díaz-Maroto, I., Vila-Lameiro, P., Díaz-Maroto, M., 2014. Influence of the canopy in the natural regeneration of Quercus robur in NW Spain. Biologia, 69 (12): 1678-1684. https://doi.org/10.2478/ s11756-014-0481-6

Wiśniewski, P., Märker, M., 2019. The role of soilprotecting forests in reducing soil erosion in young glacial landscapes of Northern-Central Poland. Geoderma, 337: 1227-1235. https://doi.org/10.1016/j.geoderma.2018.11.035

Woziwoda, B., Dyderski, M.K., Kobus, S., Parzych, A., JAGODZIŃSKI, A.M., 2019. Natural regeneration and recruitment of native Quercus robur and introduced Q. rubra in European oak-pine mixed forests. Forest Ecology and Management, 449: 117-126. https://doi.org/10.1016/j. foreco.2019.117473

ZhaO, J., YAnG, Z., Govers, G., 2019. Soil and water conservation measures reduce soil and water losses in China but not down to background levels: evidence from erosion plot data. Geoderma, 337: 729-741. https://doi. org/10.1016/j.geoderma.2018.10.023

Received January 20, 2020 Accepted April 5, 2020 